\title{
On Translation of Nicknames in Chinese Classic Novel Outlaws of the Marsh
}

\author{
Xiuqing Zhang* \\ Business College of Beijing Union University, Yanjingli Road, Beijing, China
}

Corresponding Author: Xiuqing Zhang, E-mail: mamieteaching@163.com

\begin{tabular}{l} 
ARTICLE INFO \\
\hline Article history \\
Received: June 06, 2017 \\
Accepted: August 09, 2017 \\
Published: Septmeber 01, 2017 \\
Volume: 8 Issue: 4 \\
Advance access: August 2017 \\
Conflicts of interest: None \\
Funding: None
\end{tabular}

\begin{abstract}
Chinese great classic novel Shui Hu Zhuan, also known as The Outlaws of the Marsh translated by a famed U.S.-born translator Sidney Shapiro, is rich in nicknames. In this paper, nicknames are divided mainly into five groups according to different standards. Then the author comments on Shapiro's translation in great details and draws a conclusion that Shapiro's translation is quite successful and he has made a great contribution in spreading Chinese culture to the Western world.
\end{abstract}

Key words:

Nickname,

Shui Hu Zhuan,

The Outlaws of the Marsh,

Sidney Shapiro

\section{INTRODUCTION}

Shui Hu Zhuan, written by Shi Nai'an, a writer in Ming Dynasty (1368-1644) in ancient China, is one of the Four Great Classic Novels of Chinese literature. It has been translated into different English versions by different translators from different angles. The Outlaws of the Marsh was translated by a famed U.S.-born translator Sidney Shapiro, other popular versions are as follows: All Men Are Brothers was translated by American famous writer Pearl S. Buck, Water Margin was translated by J. H. Jackson, while the most recent translation, titled The Marshes of Mount Liang was translated by Alex and John Dent-Young. This paper mainly discusses translation of nicknames in Shapiro's version.

Nickname is a name used informally instead of a person's own name, usually a short form of the actual name or a name connected with one's character or history. It usually employs the most concise and exact words to describe and indicate a person's appearance, personalities, anecdotes, personal encounters, hobbies or special skills. By using nicknames, authors are able to create a three-dimensional effect on readers and add some color to the heroes' self-image.

\section{Classifications of Nicknames in The Outlaws of the Marsh}

The Outlaws of the Marsh has been famous for its successful and vivid portrayal of the 108 heroes who have their pe- culiar nicknames respectively. It is also characterized by its colorful collection of nicknames. The Outlaws of the Marsh is a must for people to mention and quote as long as they talk about nicknames. The author Shi Nai'an used nicknames to reflect the then reality and shape heroes' images, which achieved great breakthroughs in artistic style. Here I must make clear that the same nickname may also belong to different groups according to different standards. Based on their typical characteristics, I classify them roughly into five groups as follows:

The first group is classified based on the heroes' appearance seen in table 1

The second group is connected with their personalities:(see table 2)

The third classification is based on some arms or objects:(see table 3)

Nicknames connected with animals

Some names of beasts such as dragon, tiger, snake, ape, panther, snake, scorpion, turtle, rat, dog, flea and unicorn are used to show their worship, bravery, peculiarity, skill or to protect themselves from enemies' attack. Here I'd like to mention two large groups connected with brave and ferocious dragon and tiger. The following two tables are arranged in the same order as the above three tables: 
Table 1. Heroes' appearance

\begin{tabular}{lll}
\hline Chinese names & $\begin{array}{l}\text { Chinese } \\
\text { nicknames }\end{array}$ & $\begin{array}{l}\text { English translation } \\
\text { of the nicknames by } \\
\text { Shapiro }\end{array}$ \\
\hline 林冲 & 豹子头 & The Panther Head \\
杨志 & 青面兽 & The Blue-Faced Beast \\
鲁智深 & 花和尚 & The Tattooed Monk \\
宣赞 & 丑郡马 & The Ugly Son-in-Law \\
皇甫 & 端紫鬙公 & The Purple Beard \\
王英 & 矮脚虎 & The Stumpy Tiger \\
郑天兽 & 白面郎君 & The Fair-Faced Gentleman \\
杜兴 & 鬼脸儿 & The Demon Face \\
刘唐 & 赤发鬼 & The Red-Haired Demon \\
\hline
\end{tabular}

Table 2. Personalities

\begin{tabular}{lll}
\hline Chinese names & $\begin{array}{l}\text { Chinese } \\
\text { nicknames }\end{array}$ & $\begin{array}{l}\text { English translation } \\
\text { of the nicknames by } \\
\text { Shapiro }\end{array}$ \\
\hline 秦明 & 霹䨌火 & The Thunderbolt \\
索超 & 急先锋 & The Urgent Vanguard \\
石秀 & 拼命三郎 & The Rash \\
周通 & 小霸王 & The Little King \\
燕青 & 浪子 & The Prodigy \\
李迕 & 黑旋风 & The Black Whirlwind \\
\hline
\end{tabular}

Table 3. Arms or objects

\begin{tabular}{lll}
\hline Chinese names & $\begin{array}{l}\text { Chinese } \\
\text { nicknames }\end{array}$ & $\begin{array}{l}\text { English translation of the } \\
\text { nicknames by Shapiro }\end{array}$ \\
\hline 关胜 & 大刀 & The Big Halberd \\
呼延灼 & 双鞭 & Two Rods \\
张清 & 没羽箭 & The Featherless Arrow \\
欧鹏 & 摩云金翅 & Golden Wings Brushing the \\
& & Clouds \\
孟康 & 玉笔 & The Jade Flagpole \\
蔡庆 & 一枝花 & The Single Blossom \\
\hline
\end{tabular}

Table 4. Nicknames connected with dragon

\begin{tabular}{lll}
\hline Chinese names & $\begin{array}{l}\text { Chinese } \\
\text { nicknames }\end{array}$ & $\begin{array}{l}\text { English translation of the } \\
\text { nicknames by Shapiro }\end{array}$ \\
\hline 史进 & 九纹龙 & Nine Dragons \\
李俊 & 混江龙 & The Turbulent River Dragon \\
童威 & 出洞蛟 & The Dragon from the Cave \\
邹润 & 独角龙 & The One-Horned Dragon \\
邹渊 & 出林龙 & The Dragon from the Forest \\
孙胜 & 入云龙 & Dragon in the Clouds \\
\hline
\end{tabular}

\section{An analysis of Shapiro's translation}

Nicknames in the first five tables are relatively easy to translate, for they do not carry too many cultural connotations,
Table 5. Nicknames connected with tiger

\begin{tabular}{lll}
\hline Chinese names & $\begin{array}{l}\text { Chinese } \\
\text { nicknames }\end{array}$ & $\begin{array}{l}\text { English translation } \\
\text { of the nicknames by } \\
\text { Shapiro }\end{array}$ \\
\hline 雷横 & 插翅虎 & The Winged Tiger \\
燕顺 & 锦毛虎 & The Elegant Tiger \\
龚旺 & 花项虎 & The Flowery-Necked Tiger \\
丁得孙 & 中箭虎 & The Arrow-Struck Tiger \\
李忠 & 打虎将 & The Tiger-Fighting General \\
朱富 & 笑面虎 & The Smiling Tiger \\
薛永 & 病大虫 & The Sick Tiger \\
顾大嫂 & 母大虫 & The Tigress \\
李云 & 青眼虎 & The Black-eyed Tiger \\
\hline
\end{tabular}

Table 6. Some nicknames based on Chinese ancient heroes, religion or allusions

\begin{tabular}{lll}
\cline { 2 - 3 } Chinese names & $\begin{array}{l}\text { Chinese } \\
\text { nicknames }\end{array}$ & $\begin{array}{l}\text { English translation } \\
\text { of the nicknames by } \\
\text { Shapiro }\end{array}$ \\
\hline 花荣 & 小李广 & The Lesser Liguang \\
吕方 & 小温侯 & The Little Duke \\
郭盛 & 赛仁贵 & The Second Rengui \\
项充 & 八臂哪吒 & Eight-Armed Nezha \\
李衰 & 飞天大圣 & The Flying Divinity \\
孙立 & 病尉迟 & The Sickly General \\
孙新 & 小尉迟 & The Junior General \\
杨雄 & 病关索 & The Pallid \\
\hline
\end{tabular}

and I notice that Shapiro mainly adopted literal translation in dealing with these names. As a result, most of his translation was able to convey the basic ideas of the source nicknames. I summarize his translation into three groups:

\section{Good Translation}

Take some translation as an example: he translated “鬼脸 儿”as The Demon Face, “赤发鬼”as The Red-Haired Demon, “没羽箭” as The Featherless Arrow, “玉笔” as The Jade Flagpole, “一枝花” as The Single Blossom and“青眼 虎”as The Black-eyed Tiger. Basically, it is word for word translation, all of which is as vivid and lively as the original ones. When we read the Chinese nicknames, a clear and lifelike picture will emerge in our mind, and similarly, when we read the English versions, we share the same feelings.

At the same time, Shapiro introduced and spread China's culture to the Westerners. In feudal China, dragon was the symbol of emperors. The Chinese dragon is said to have the head of a camel, the horns of a deer, the eyes of a rabbit, the ears of a cow, the neck of a snake, the belly of a frog, the scales of a carp, the claws of a hawk, and the palm of a tiger. It has whiskers and a beard, and it is deaf. It is generally regarded as benevolent. As a matter of a fact, dragon is the cre- 
ation of our ancestors' imagination. What the dragon is like is of little significance, but what is important is that it is now a kind of cultural phenomenon. It has become a spiritual tie linking the whole nation. So we can say, the dragon, as the symbol of the Chinese nation, has become part of the Chinese people (Yuan, p.298). Therefore in Chinese, the word dragon is always associated with good things and appearing usually together with 凤(phoenix). We have such Chinese idioms as 龙飞凤舞、龙凤呈祥、龙盘虎踞、藏龙卧虎、 龙驹风维、龙马精神、攀龙附风、画龙点睛,etc. Now all of the Chinese people claim to be the offspring of the Dragon.

On the contrary, a dragon is not popular with the Westerners. In Western mythology, a dragon is a large imaginary animal with wings of a bat and huge flaws. It breathes out fire and smoke, and is so ferocious and destructive that people have traditionally considered it a symbol of evils fought by human beings.(Hao, p.94) In their eyes, dragon is a large monster. When we call a woman a dragon, it means that she is fierce and unpleasant. So a dragon in Chinese and in English is quite different. When we translate the dragon, we should pay more attention to its connotations in these two languages. Let's turn back to Shapiro's translation. Evidently, he adopted the auspicious meaning of dragon in Chinese and translated“出洞蛟” as The Dragon from the Cave and“" 独角龙” 'as The One-Horned Dragon which was fit for Chinese people's habit and simultaneously opened a new horizon for the Westerners.

Such nicknames as“小李广”, “赛仁贵”and “八臂哪 吒"were translated with Chinese characteristics. They are good except when the target readers read such translation for the first time, they may not know who Liguang, Rengui and Nezha are, so I suggest that some explanations and allusions should be added to these Chinese famous names to make them clear and easily acceptable.

In my opinion, “小霸王”and“黑旋风”are best translated. When it comes to TheLittle King, we can't help thinking of "the little emperor" which is a household word in China.

The Black Whirlwind first appeared in chapter 38 from page 779 to 799 of the English Version(Note 1). Here Black was used to describe Li Kui's complexion (facial features), while Whirlwind showed that, on the one hand, he was as fast and violent as a whirlwind, and on the other hand, he swept across everything like a whirlwind. For example, when he had some wine with Dai Zong and Song Jiang, he said "All right, but none of those piddling little cups for me. I want a large bowl." When they ate fish, he pulled the fish out of his bowl with his hand and ate it, bones and all. Compared with him, Song Jiang ate with elegance. Considering the fish was not fresh, Song Jiang took two sips of soup and stopped eating. Dai Zong didn't like salted fish either. Li Kui who had finished his own bowl said: "If you brothers don't want yours, I'll eat it for you." He scooped the fish out of Song Jiang's bowl with his fingers and consumed it, then did the same with Dai Zong's. He spattered the whole table with soup(Note 2). From his speech and manners we can see that Li Kui was a straight-forward loyal fellow, but he was rude and rash. The slightest injustice drove him wild, and he tore into bullies. In short, this part of translation is translated successfully and vividly manifesting Li Kui's true characters.

\section{Mistaken Translation}

In Table 2, “浪子”was mistakenly translated as The Prodigy. I consult Longman Dictionary of Contemporary English and its explanation is a person who has unusual and very noticeable abilities. So “浪子”does not mean Prodigy. I find another translation for “浪子”-----The Prodigal. In that dictionary, it explains that prodigal is a person who leads a life of careless wasteful spending and perhaps immoral pleasure and its Chinese equivalent is 浪子 or 奢侈挥霍的人, so from my perspective The Prodigal should be a proper and exact translation.

\section{Poor or Under Translation}

Some culturally-loaded nicknames were under-translated which can not express the source nicknames exactly. Take“" 花和尚”for an example. “花和尚” is a pun in source language and has two meanings, one is that Lu Zhisheng's back was tattooed and the other is that he did not observe the disciplines of Buddhism which required that monk should be a reverent Buddhist and practice vegetarianism, and not drink any wine, kill people or set fire. But Lu Zhisheng did all of the things above out of various reasons. So The Tattooed Monk only translated its Chinese literal meaning instead of its connotations. Here I try translating “花和尚” as The Undisciplined Tattooed Monk.

Nicknames in Table 6 are closely related with some ancient heroes, religion or allusions which are the most difficult to translate, for they carry too much information. For example, “小温侯”吕方 was translated as The Little Duke, here Duke confused readers. “温候”was Lü Bu’s（吕布,a figure in the novel Three Kingdoms ) literary name given by Wang Yun (王允) after Lü Bu helped assassinate Dong Zhuo(董卓). Lü Fang liked to imitate Lü Bu including using the same weapon-----halberd,what's more, Lü Fang had the same surname as $\mathrm{Lü} \mathrm{Bu}$, hence his nickname was 小温 侯.When it was translated as The Little Duke, the social background reflected in the name completely disappeared. I translate it as The Little Wen Hou.

Sunli and Sunxin's nicknames are taken from a famous general of Tang Dynasty----Yu Chigong(尉迟恭) who led his army to defeat the uprising of Wang Shichong (王世充) and Dou Jiande(窦建德), etc and rendered outstanding service for the Emperor Li Shiming(李世明). When “病尉迟”and “小尉 迟”were translated as The Sickly General or The Junior General,the basic meaning of 尉迟 did not exist, nor did Chinese historical culture hidden in their nicknames. Here I translate them as The Sickly Yuchi and The Lesser Yuchi respectively. When the two English versions appeared for the first time in the novel, the translator should explain Yuchi in great details.

Similarly,杨雄”s nickname“病关索”was translated as The Pallid, which described only his complexion instead of the allusion about Guan Suo (关索). It is said that Guan Suo was a young and handsome man with weapons and the third son of Guan Yu (关羽) (a figure in another Chinese classical novel Three Kingdoms). But病关索means that杨雄's com- 
plexion is rather pale and he is like Guan Suo in some aspect. So I translate it as The Sick Guan Suo.

\section{CONCLUSION}

Language is the carrier of culture, spreading and reflecting culture. Nicknames in the source language are colorful, vivid, impressive, interesting and frequently quoted. Nicknames translated by Shapiro are able to convey the basic information of the source language, although there do exist some defects. On the whole, Shapiro's translation is vivid and precise. He had made a lot of contributions to introducing China's ancient civilization and culture to the Westerners and widened their horizons.

\section{Notes}

Note $1 \&$ 2. The Outlaws of the Marsh, translated by Sidney Shapiro. Volume II. Beijing: Beijing Foreign Languages Press, 1988, pp.779 --799.

\section{REFERENCES}

Hao P. (2016). The Traditional Beliefs, Legends and Customs of the British and Americans. Hai Kou: Nan Hai Publishing House.

Ji, Q. (2004). The Introduction and Results of the 108 Characters in the Water Margin. Journal of Weifang University, 4(9), 7-13.

Kong Lingbin,(2004). Comments on the nicknames of the Characters in A Dream of Red Mansions. Academic Forum of $\mathrm{NanDu}, 24(6), 52-54$.

Liu, T, (2014).On the Translation of Character Nicknames relating to Animal Metaphor from the Perspective of Conceptual Metaphor: A Case Study of Shu Hu Zhuan. Journal of Kaili University, 32(1),97-100.

Xu, X. (2001). On Shapiro's Translation of the Marsh Heroes' Nicknames Characters. Journal of Zhanjiang Normal College, 22(10), 96-98.

Yuan, Z. (2016). English Guide to Beijing. Beijing: Tourism and Education Publishing House. 